\title{
PENGARUH KOMBINASI PENGKABUTAN DAN KIPAS ANGIN TERHADAP KONDISI FISIOLOGIS SAPI PERAH PERANAKAN FRIESIAN HOLLAND
}

\section{COMBINED EFFECTS OF SPRINKLER AND FAN ON PHYSIOLOGICAL CONDITIONS OF FRIESIAN HOLLAND DAIRY CATTLE}

\author{
John Arnold Palulungan ${ }^{1 *}$, Adiarto ${ }^{2}$, dan Tety Hartatik ${ }^{2}$ \\ ${ }^{1}$ Fakultas Peternakan, Perikanan dan Ilmu Kelautan, Universitas Negeri Papua, Jl. Gunung Salju, Amban, Manokwari, \\ 98314 \\ ${ }^{2}$ Fakultas Peternakan, Universitas Gadjah Mada, Jl. Fauna No. 3, Bulaksumur, Yogyakarta, 55281
}

\section{INTISARI}

Penelitian ini bertujuan mengetahui pengaruh pengkabutan yang dikombinasi dengan penggunaan kipas angin terhadap kondisi mikroklimat kandang, kondisi fisiologis, dan konsumsi pakan. Delapan ekor sapi perah yaitu 4 ekor laktasi ke I dan 4 ekor laktasi ke III, dengan rata-rata berat badan 409,13 $\pm 19,02 \mathrm{~kg}$ dikelompokkan dalam dua kelompok. Metode yang digunakan metode eksperimen yang dirancang dengan rancangan balanced simple crossover dengan dua perlakuan yaitu pengkabutan dan kipas angin (P) dan tidak dilakukan pengkabutan dan kipas angin (TP) sebagai kontrol. Pelaksanaan penelitian ini dilaksanakan dalam dua tahap. Sebelum dilakukan periode perlakuan terlebih dahulu dilakukan penelitian tahap awal untuk mengamati titik-titik kritis kapan waktu yang tepat dilakukan pengkabutan. Pada penelitian awal diperoleh titik-titik kritis pada jam 10.00, 12.00, 13.00, 14.00, dan 16.00. Pada awal perlakuan pengkabutan terlebih dahulu dilakukan masa adaptasi pada sapi perah selama 1 minggu. Parameter yang diamati meliputi mikroklimat kandang, kondisi fisiologis, dan konsumsi bahan kering pakan. Data yang diperoleh dianalisis menggunakan analisis varian. Hasil penelitian diperoleh kondisi mikroklimat kandang yaitu; temperatur kandang sangat berbeda nyata $(\mathrm{P} \leq 0,01)$ pada kelompok perlakuan $\mathrm{P}$ dan $\mathrm{TP}$ berturut-turut $27,91 \pm 1,58$ dan $29,41 \pm 2,34^{\circ} \mathrm{C}$, kelembaban kandang berbeda nyata $(\mathrm{P} \leq 0,05)$ berturut-turut $73,64 \pm 8,73$ dan $71,40 \pm 10,35 \%$, dan Temperature-Humidity Index sangat berbeda $(\mathrm{P} \leq 0,01)$ yaitu $76,42 \pm 1,23$ dan $78,03 \pm 1,99$. Kondisi fisiologi yaitu temperatur rektal berbeda nyata $(\mathrm{P} \leq 0,05)$ pada kelompok perlakuan $\mathrm{P}$ dan $\mathrm{TP}$ berturut-turut $38,58 \pm 0,35$ dan $38,82 \pm 0,41^{\circ} \mathrm{C}$, laju pulsus berbeda nyata $(\mathrm{P} \leq 0,05)$ yaitu $64,12 \pm 5,96$ dan $68,44 \pm 5,85$ denyutan/menit, laju respirasi sangat berbeda $(\mathrm{P} \leq 0,01)$ yaitu $23,56 \pm 3,36$ dan 33,56 $\pm 8,02$ dengusan/menit. Perlakuan pengkabutan dan kipas angin selama 10 menit dapat menurunkan temperatur lingkungan dalam kandang, efektif menurunkan Temperature-Humidity Index, serta temperatur rektal, laju pulsus, dan laju respirasi ternak, namun menaikkan kelembaban dalam kandang. Stres panas yang dialami ternak belum mempengaruhi konsumsi pakan.

(Kata kunci: Sapi Friesian Holland, Heat stress, Pengkabutan dan kipas, Kondisi fisiologis ternak, Mikroklimat kandang)

\section{ABSTRACT}

This study aim to determine the influence of the combination of sprinkler and fan on the microclimate condition of the pen, physiological condition of cattle and feed consumption of Friesian Holland (FH) dairy cattle. A total of eight dairy lactating cows were used, four (4) in their first lactation and the other four in their third lactation. Experimental animals had an average body weight of $409.13 \pm 19.02 \mathrm{~kg}$ and were divided into two groups. The experimental method was a simple balanced crossover design with two treatments; the sprinkler fan $(P)$ and non sprinkler and fans (TP) as a control. Implementation of the research was conducted in two phases. Before the first treatment period, an early stage research was conducted to observe the critical points of the appropriate time to carry out sprinkling. The pre-study obtained critical points at 10.00,12.00, 13.00, 14.00 and 16.00. At the beginning of the treatment, experimental animals underwent an adaptation period in the first week. The parameters observed were microclimate of pen, the physiological conditions of the cows and dry matter feed intake. Data were analyzed using analysis of variance. The results showed the pen temperature conditions were significantly different $(P \leq 0.01$ between the treated group $P$ and TP i.e. 27.91 \pm 1.58 and $29.41 \pm 2.34^{\circ} \mathrm{C}$ respectively, humidity of enclosure were significantly different $(P \leq 0.05)$ i.e. $73.64 \pm 8.73$ and $71.40 \pm 10.35 \%$ respectively and Temperature-Humidity Index were significantly different $(P \leq 0.01) 76.42 \pm 1.23$ and $78.03 \pm 1.99$. While the physiological condition and rectal temperature were significantly different $(P \leq 0.05)$ between the treated group $P$ and TP at $38.58 \pm 0.35$ and $38.82 \pm 0.41^{\circ} \mathrm{C}$ respectively, pulse rate was significantly different $(P \leq 0.05)$ at $64.12 \pm 5.96$ and $68.44 \pm 5.85$ beats/minute, respiration rate were also significantly different $(P \leq 0.01)$ at $23.56 \pm 3.36$ and $33.56 \pm 8.02$ grunts/minute. Treatment with sprinkler fan for 10 minutes can reduce the temperature inside the pen,

\footnotetext{
* Korespondensi (corresponding author):

Telp. +6281344072838

E-mail: palulungan.john@gmail.com
} 
effectively to lowering the Temperature-Humidity Index, as well as rectal temperature, pulse rate, and respiration rate of cattle, but raised the humidity in the pen. The heat stress did not affect feed intake.

\section{(Key words: Friesian Holland cattle, Heat stress, Sprinklers and fans, Physiological conditions of livestock, Pen} microclimate)

\section{Pendahuluan}

Sapi perah Friesian Holland (FH) dikenal sebagai sapi perah berkemampuan produksi susu tinggi yang berasal dari daerah temperate (kawasan bersuhu dingin). Temperatur di daerah tersebut berkisar antara 5 sampai $15^{\circ} \mathrm{C}$ (Yani dan Purwanto, 2006). Sapi ini diimpor oleh pemerintah Indonesia dari Australia, New Zealand, atau bahkan dari Amerika Serikat, untuk meningkatkan populasi ternak dan produksi susu dalam negeri. Diharapkan dengan mengimpor sapi $\mathrm{FH}$ dapat mengurangi semakin besarnya ketergantungan susu impor dalam upaya memenuhi kebutuhan susu dalam negeri.

Penggunaan bangsa sapi perah keturunan Bos taurus seperti sapi FH di daerah tropis (basah) seperti Indonesia memiliki kendala, salah satunya adalah tingginya suhu lingkungan dan kelembaban udara. Suhu udara dapat mencapai $24-34^{\circ} \mathrm{C}$ dan kelembaban 60-90\% (Yani et al., 2007). Pemindahan sapi FH tersebut ke lingkungan tropis menyebabkan turunnya kinerja sapi secara umum, seperti produksi dan kualitas susu, dan kinerja reproduksinya atau yang dikenal Tropical Degeneration yang besarnya kira-kira 30\% dari kemampuan genetiknya. Penurunan kinerja tersebut diperkirakan sebagai dampak langsung maupun tidak langsung iklim tropis. Dampak langsung dari lingkungan tropis akan menyebabkan sulitnya proses pelepasan panas dari tubuh sapi (body heat dissipation) sebagai akibat tingginya temperatur lingkungan dan kelembaban udara, sehingga sapi mengalami stres panas (heat stress).

Dampak stres panas menyebabkan turunnya konsumsi bahan kering (BK) dan tingginya konsumsi air sebagai akibat dehidrasi, sehingga berdampak rendahnya konsumsi nutrien untuk menjaga produktivitas ternak. Pada kondisi ekstrim sapi cenderung mengurangi konsumsi BK, bahkan berhenti sama sekali mengkonsumsi pakan. Berhentinya mengkonsumsi pakan salah satu upaya ternak untuk mengurangi body heat load (beban panas tubuh) untuk menurunkan produksi panas hasil proses metabolisme pakan. Sapi perah menanggapi tekanan panas dengan beberapa cara, yaitu: 1) mengurangi asupan pakan, 2) meningkatkan asupan air, 3) tingkat metabolisme berubah untuk kebutuhan pemeliharaan, 4) peningkatan kehilangan air melalui penguapan, 5) peningkatan laju respirasi, 6) konsentrasi hormon dalam darah berubah, dan 7) peningkatan suhu tubuh (Amstrong, 1994).

Ide untuk memperbaiki persusuan di daerah tropis sudah mulai ditempuh dengan beberapa cara antara lain: 1) menggunakan breed sapi perah tropis; 2) melakukan cross breed antara Bos indicus dan Bos taurus (Australian Milking Zebu (AMZ), Australian Friesian Sahiwal (AFS), dan lain sebagainya); 3) memperbaiki/memanipulasi kondisi lingkungan agar proses desipasi panas berlangsung efisien; dan 4) memberi pakan yang menghasilkan panas metabolis (heat increament) yang rendah, seperti penggunaan lemak dalam ransum.

Salah satu upaya manipulasi lingkungan mikroklimat kandang yang dapat dilakukan untuk menurunkan suhu lingkungan di dalam kandang adalah pengkabutan. Pengkabutan dengan menggunakan air yang diubah menjadi kabut melalui nozel diharapkan dapat mereduksi panas dari tubuh dan daerah di sekitar ternak, sehingga kondisi lingkungan yang mendekati kondisi lingkungan yang nyaman atau Temperature-Humidity Index (THI) mendekati 72 dapat terwujud dengan penggunaan pengkabutan. Temperature-Humidity Index kurang dari 72 merupakan batas normal ternak perah (Chase, 2006), namun penggunaan kabut dapat juga meningkatkan kelembaban dalam kandang. Salah satu cara untuk mengurangi kelembaban digunakan kipas angin agar partikelpartikel air di udara dapat bergerak keluar kandang. Berdasarkan uraian di atas maka perlu dilakukan penelitian pengkabutan yang dikombinasikan dengan kipas angin terhadap mikroklimat kandang dan kondisi fisiologis sapi perah FH di daerah tropis dataran rendah.

Tujuan dari penelitian ini untuk mengetahui pengaruh pengkabutan yang dikombinasikan dengan penggunaan kipas angin terhadap kondisi mikroklimat kandang, kondisi fisiologis, dan konsumsi pakan ternak. Manfaat dari penilitian ini sebagai tambahan informasi bagi pelaku pembangunan di subsektor peternakan khususnya dalam manajemen sapi perah di daerah tropis.

\section{Materi dan Metode}

Penelitian ini dilaksanakan di UPT Ternak Perah, Fakultas Peternakan, Universitas Gadjah Mada pada bulan Januari - Maret 2012. Ternak yang digunakan dalam penelitian ini adalah sapi betina FH sebanyak 8 ekor dimana 4 ekor laktasi I 
dan 4 ekor laktasi III dengan rata-rata berat badan $409,13 \pm 19,02 \mathrm{~kg}$, kemudian ditempatkan pada kandang stanchion secara individu. Alat yang digunakan selama penelitian adalah kandang, satu unit mesin pengkabut, kipas angin, termometer maksimum-minimum, dua buah dry-wet bulb, termometer digital klinik rectal microlife, stop watch/timer, timbangan dengan kapasitas $5 \mathrm{~kg}$, selang, skop, ember, dan alat tulis menulis.

Metode yang digunakan dalam penelitian ini adalah metode eksperimen yang dirancang dengan rancangan balanced simple crossover designs dengan perlakuan yang diujikan, yaitu:

$\mathrm{P} \quad$ : kelompok yang dalam perlakuan pengkabutan dan kipas angin

TP : kelompok yang tidak dilakukan pengkabutan dan kipas angin (sebagai kontrol)

\section{Pelaksanaan penelitian}

Pelaksanaan penelitian ini dibagi dalam dua tahap yaitu tahap I penelitian awal dan tahap II penelitian.

Tahap I penelitian awal. Semua ternak yang digunakan dikelompokkan secara acak menjadi dua kelompok (A dan B). Masing-masing kelompok terdiri atas 4 ekor. Kedua kelompok ternak ditempatkan dalam kandang, berlantai semen (concrete floor) yang dilengkapi tempat pakan dan air minum.

Penelitian awal bertujuan untuk mengetahui perubahan kondisi fisiologis ternak perah yang disesuaikan dengan aktivitas manajemen pemeliharaan di UPT Ternak Perah Fakultas Peternakan UGM. Pengamatan dilakukan selama 24 jam dimulai dari jam 06.00 pagi hingga selama satu minggu.

Hasil pengamatan awal ini akan diperoleh waktu yang tepat untuk dilakukan pengkabutan dan kipas angin pada sapi kelompok perlakuan. Aktivitas pada kegiatan penelitian awal tersaji pada Gambar 1.
Tahap II penelitian. Proses perlakuan pengkabutan dan kipas angin dilaksanakan berdasarkan hasil penelitian awal, dimana diperoleh data waktu yang tepat untuk dilakukan perlakuan kombinasi pengkabutan dan kipas angin. Pelaksanaan perlakuan kombinasi pengkabutan dan kipas angin ini diawali dengan masa penyesuaian selama satu minggu dan diikuti tiga minggu perlakuan. Pada periode perlakuan kelompok A mendapat perlakuan kombinasi pengkabutan dan kipas angin (P) dan kelompok B tidak (TP). Kemudian pada periode II kelompok A sebagai kontrol dan kelompok B yang mendapat perlakuan. Baik pada masa penyesuaian maupun masa perlakuan dilakukan pengambilan data terhadap semua parameter yang diteliti.

Nozel tempat keluarnya kabut dihubungkan oleh slang karet dengan jarak antar nozel panjang $\pm 50 \mathrm{~cm}$, nozel tersebut ditempatkan dengan ketinggian $\pm 3 \mathrm{~m}$ dari atas lantai kandang. Slang distribusi dihubungkan ke sebuah mesin pompa dan selanjutnya ke sumber air atau tempat penampung. Sebelum dilakukan perlakuan kombinasi pengkabutan dan kipas angin, dilakukan pengukuran parameter kondisi fisiologis yakni temperatur rektal, laju pulsus, dan respirasi untuk kedua kelompok ternak. Pengukuran selanjutnya dilakukan setelah pengkabutan dan kipas angin, dengan maksud untuk melihat perubahan kondisi mikroklimat kandang dan fisiologi ternak terhadap perlakuan yang diterapkan. Lama proses pengkabutan dan kipas angin dilakukan selama 10 menit. Kondisi mikroklimat kandang diobservasi setiap jam dimulai dari jam 06.00 sampai jam 16.00 selama penelitian. Kondisi temperatur udara maksimum dan minimum harian diamati setiap jam dengan membaca skala pada termometer maksimumminimum.

Pakan yang diberikan mengikuti manajemen pemeliharaan UPT Ternak Perah Fakultas Peternakan UGM yaitu rumput dan konsentrat (campuran polar dan ampas tahu). Sampel bahan

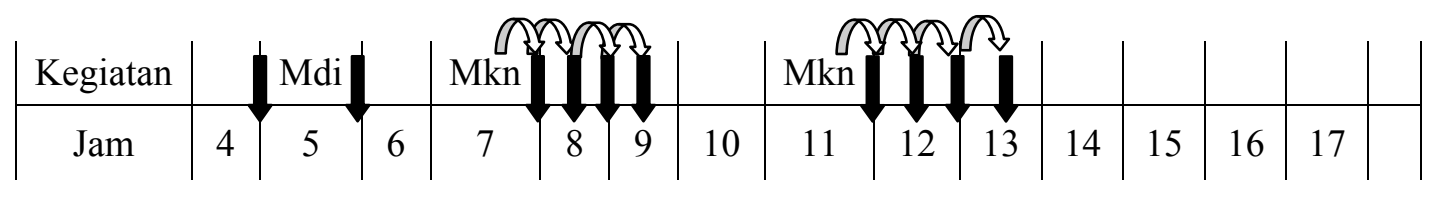

Ket:

Mdi = mandi

Mkn = makan

$=$ Pengamatan fisiologi

$=30$ menit

$\Omega$

Gambar 1. Aktivitas pada kegiatan penelitian awal (beginning of research activity). 
pakan yang digunakan dievaluasi di laboratorium untuk mengetahui kandungan BK.

Parameter yang diamati dalam penelitian ini yaitu: 1) mikroklimat kandang; kondisi mikroklimat kandang yang diamati meliputi; temperatur kandang $\left({ }^{\circ} \mathrm{C}\right)$, kelembaban kandang (\%), dan TemperatureHumidity Index (THI) kandang; 2) kondisi fisiologis, meliputi: temperatur rektal, laju respirasi, dan pulsus yang diukur setelah pengkabutan dan kipas angin; temperatur rektal $\left({ }^{\circ} \mathrm{C}\right)$, laju respirasi (denyutan/menit), dan laju pulsus (denyutan/menit); 3) konsumsi bahan kering pakan. Data yang dikumpulkan diolah dan dianalisis menggunakan analisis variansi (Gaspersz, 1992).

\section{Hasil dan Pembahasan}

\section{Kondisi mikroklimat}

Hasil kondisi mikroklimat kandang yang diamati dalam penelitian ini meliputi: temperatur kandang, kelembaban, dan Temperature-Humidity Index (THI) disajikan pada Tabel 1.

Hasil pengukuran temperatur kandang untuk kelompok perlakuan (kombinasi pengkabutan dan kipas angin) dan kelompok tidak dilakukan pengkabutan dan kipas angin (kontrol) selama dua periode percobaan menunjukkan temperatur kandang untuk kelompok perlakuan tercatat minimum $25,48^{\circ} \mathrm{C}$ jam 06.00 dan maksimum $30,90^{\circ} \mathrm{C}$ jam 11.00 , sedangkan kelompok kontrol tercatat suhu minimum $25,48^{\circ} \mathrm{C}$ jam 06.00 dan maksimum $32,44^{\circ} \mathrm{C}$ jam 13.00 . Rata-rata temperatur kandang pada kelompok perlakuan lebih rendah $\left(28,93^{\circ} \mathrm{C}\right)$ dibandingkan kelompok kontrol $\left(29,41^{\circ} \mathrm{C}\right)$. Berdasarkan hasil analisis variansi menunjukkan rata-rata temperatur kandang kedua kelompok perbedaan sangat nyata $(\mathrm{P} \leq 0,01)$.

Hasil pengukuran kelembaban kandang untuk kelompok perlakuan dan kelompok kontrol yang diperoleh dua periode percobaan, secara statistik menunjukkan rata-rata kelembaban kandang kedua kelompok berbeda nyata $(\mathrm{P} \leq 0,05)$. Hasil penelitian menunjukkan kelembaban kandang kelompok perlakuan kombinasi pengkabutan dan kipas angin tercatat minimum $58,92 \%$ pada jam 11.00 dan maksimum 90,30\% pada jam 06.00 dan untuk kelompok kontrol tercatat minimum 55,67\% pada jam 13.00 dan maksimum 90,75\% pada jam 06.00. Rata-rata kelembaban kandang untuk kelompok perlakuan $73,64 \pm 8,73 \%$ sedangkan untuk kelompok kontrol $71,40 \pm 10,35 \%$. Pola perubahan kelembaban kandang untuk kedua kelompok disajikan pada Gambar 2.

Hasil pengukuran THI kandang tercatat untuk kelompok perlakuan kombinasi pengkabutan dan kipas angin maksimal 78,92 pada jam 15.00 dan minimum 74,10 pada jam 6.00 dengan rata-rata $76,42 \pm 1,23$ dan untuk kelompok kontrol THI kandang maksimum 81,40 jam 13.00 dan minimum 74,10 jam 6.00 dengan 78,03 $\pm 1,99$. Secara statistik rata-rata THI kandang sangat berbeda nyata $(\mathrm{P} \leq 0,01)$. Gambar 2 menunjukkan pola perubahan temperatur, kelembaban, dan THI kandang untuk kedua kelompok perlakuan.

Dari grafik temperatur pada Gambar 2 terlihat bahwa untuk kelompok perlakuan mengalami penurunan sangat nyata $(\mathrm{P} \leq 0,01)$. Selisih antara kelompok perlakuan dan kontrol sebesar $2,56 \pm 1,31^{\circ} \mathrm{C}$. Adanya perbedaan temperatur ini diduga karena kabut air dari nozel melewati ruang atmosfer dan menyerap panas sehingga temperatur atmosfer di kelompok perlakuan lebih rendah dibandingkan kelompok kontrol.

Pada kelompok perlakuan terjadi kenaikan temperatur dari $25,48^{\circ} \mathrm{C}$ (jam 6.00) sampai $28,36^{\circ} \mathrm{C}$ (jam 9.00). Pada jam 10.00 turun menjadi $27,79^{\circ} \mathrm{C}$. Pada kelompok perlakuan terjadi peningkatan temperatur $30,90^{\circ} \mathrm{C}$ jam 11.00 dan $29,43^{\circ} \mathrm{C}$ jam 15.00. Hal ini dikarenakan pada jam 11.00 dan 15.00 tidak dilakukan perlakuan. Selain itu adanya pengaruh panas yang berasal dari atap yang sangat mempengaruhi suhu mikro kandang kelompok perlakuan. Suhu udara dalam kandang memiliki kecenderungan meningkat dari posisi dekat lantai menuju posisi dekat atap (Yani et al., 2007).

Konstruksi kandang sangat mempengaruhi temperatur kandang, diantaranya tinggi kandang dan bahan atap yang digunakan. Menurut Yani et al. (2007) hasil simulasi kandang tail to tail menghasilkan temperatur mikroklimat kandang

Tabel 1. Rata-rata temperatur kandang, kelembaban, dan Temperature-Humidity Index (THI) (average of pen temperature, humidity and Temperature-Humidity Index (THI))

\begin{tabular}{lccc}
\hline \hline \multicolumn{1}{c}{ Parameter } & $\begin{array}{c}\text { Pengkabutan dan } \\
\text { kipas angin (sprinkler } \\
\text { and fan) }\end{array}$ & $\begin{array}{c}\text { Kontrol } \\
(\text { control })\end{array}$ & $\begin{array}{c}\text { Signifikansi } \\
\text { (significancy) }\end{array}$ \\
\hline Temperatur kandang $\left({ }^{\circ} \mathrm{C}\right)\left(\right.$ pen temperature $\left.\left({ }^{\circ} \mathrm{C}\right)\right)$ & $27,91 \pm 1,58$ & $29,41 \pm 02,34$ & $* *$ \\
Kelembaban $(\%)($ humidity $(\%))$ & $73,64 \pm 8,73$ & $71,40 \pm 10,35$ & $*$ \\
Temperature-Humidity Index $(\mathrm{THI})$ & $76,42 \pm 1,23$ & $78,03 \pm 01,99$ & $* *$ \\
\hline
\end{tabular}

$*(\mathrm{P} \leq 0,05),{ }^{* *}(\mathrm{P} \leq 0,01)$. 
(a)

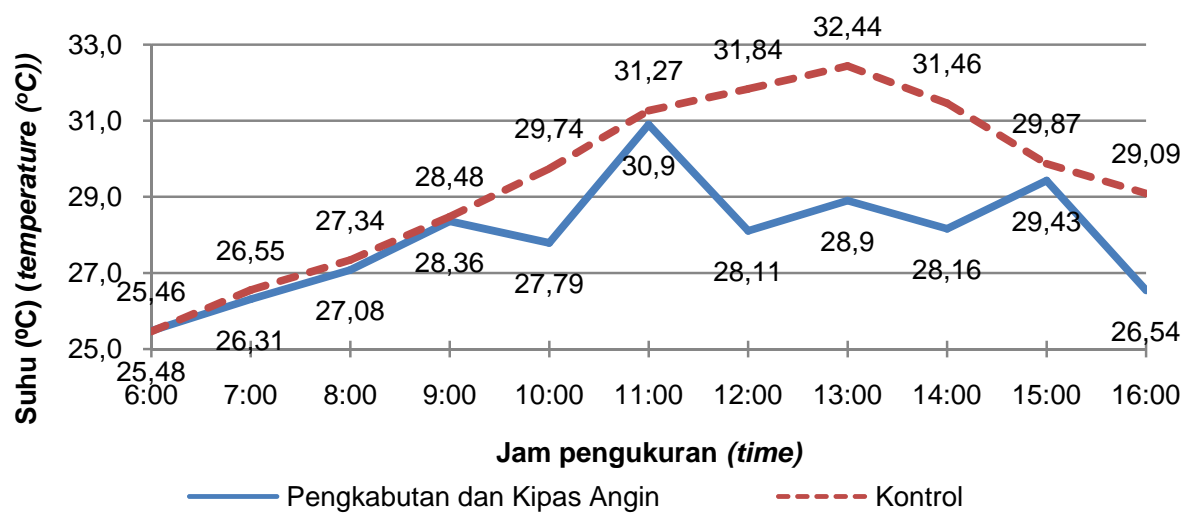

(b)

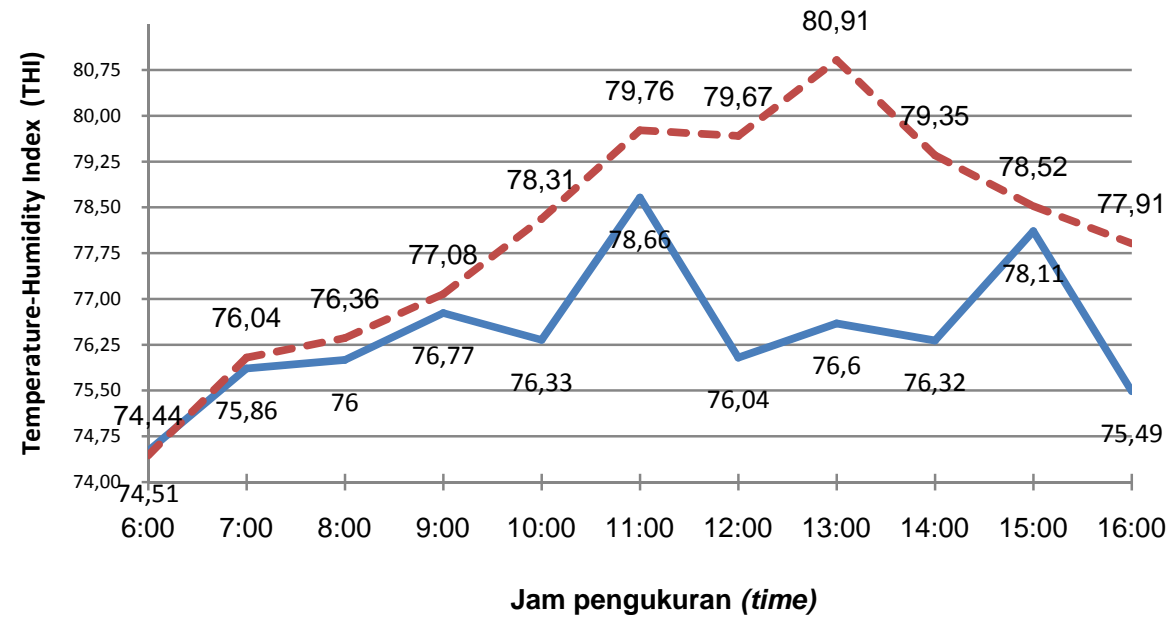

— Pengkabutan dan Kipas Angin _ ----- Kontrol

(c)

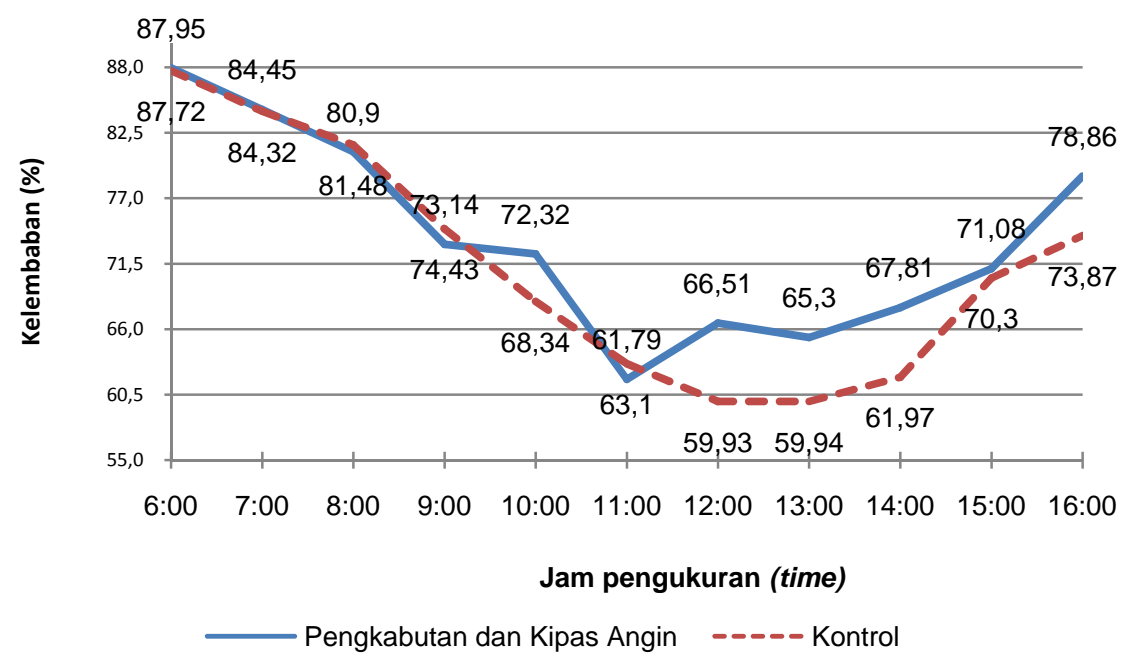

Gambar 2. Grafik pola perubahan temperatur (a), Temperature-Humidity Index (b), dan kelembaban kandang

(c) untuk kedua kelompok perlakuan (graphic of temperature change pattern (a), Temperature-Humidity Index (b) and humidity pen (c) for two treatments).

yang rendah dengan ukuran tinggi $6,25 \mathrm{~m}$, lebar 8,3 $\mathrm{m}$, dan tinggi dinding $0,4 \mathrm{~m}$. Yani dan Purwanto (2006) menyarankan penggunaan atap dengan kemampuan konduktivitas yang rendah sehingga kemampuan bahan atap untuk menghantar radiasi panas yang diserap menjadi rendah.
Dari Gambar 2 terlihat kelembaban pada saat dilakukan perlakuan kombinasi pengkabutan dan kipas angin. Kelembaban untuk kelompok perlakuan 73,14\% (jam 10.00), 66,51\% (jam 12.00), $65,30 \%$ (jam 13.00), 67,81\% (jam 14.00) dan $78,86 \%$ (jam 16.00), sedangkan untuk kelompok kontrol 68,34\% (jam 10.00), 59,94\% (jam 12.00), 
59,94\% (jam 13.00), 61,97\% (jam 14.00) dan $73,87 \%$ (jam 16.00). Tingginya kelembaban pada kelompok perlakuan ini dikarenakan pada saat perlakuan pengkabutan dan kipas angin, kabut air yang dihasilkan oleh nozel menambah kandungan air di atmosfer. Pada jam 11.00 dan 15.00 terlihat kelembaban untuk kelompok perlakuan hampir mendekati kelembaban kelompok kontrol. Hal ini dikarenakan tidak dilakukan perlakuan kombinasi pengkabutan dan kipas angin pada jam tersebut. Secara keseluruhan perlakuan ini mengakibatkan kelembaban meningkat pada kelompok perlakuan sebesar 2,25\% dibandingkan kelompok kontrol.

Dari Gambar 2 terlihat THI pada saat dilakukan perlakuan kombinasi pengkabutan dan kipas angin. Temperature-Humidity Index (THI) untuk kelompok perlakuan 76,33 (jam 10.00), 76,04 (jam 12.00), 76,60 (jam 13.00), 76,32 (jam 14.00) dan 75,49 (jam 16.00), sedangkan untuk kelompok kontrol 78,31 (jam 10.00), 79,67 (jam 12.00), 80,91 (jam 13.00), 79,35 (jam 14.00) dan 77,91 (jam 16.00). Terlihat dari gambar terjadi perbedaan THI kandang pada saat dilakukan perlakuan kombinasi pengkabutan dan kipas angin. Pada kelompok perlakuan THI lebih rendah dari kelompok kontrol. Hal ini masih dipengaruhi oleh adanya pengaruh suhu yang rendah dibandingkan suhu kelompok kontrol walaupun terdapat perbedaan kelembaban yang tinggi dibandingkan kelompok kontrol.

\section{Kondisi fisiologi}

Variabel kondisi fisiologi sapi FH yang diamati dalam penelitian ini meliputi temperatur rektal, laju pulsus, dan laju respirasi tersaji pada Tabel 3.

Hasil pengukuran temperatur rektal sapi $\mathrm{FH}$ yang merupakan respon dari perlakuan menunjukkan rata-rata temperatur rektal ternak untuk perlakuan kombinasi pengkabutan dan kipas angin $38,58 \pm 0,35^{\circ} \mathrm{C}$ dan kontrol $38,82 \pm 0,4^{\circ} \mathrm{C}$. Analisis variansi temperatur ternak ketika mendapatkan perlakuan kombinasi pengkabutan dan kipas yang dibandingkan kontrol berbeda nyata $(\mathrm{P} \leq 0,05)$.
Hasil pengukuran laju pulsus sapi $\mathrm{FH}$ yang merupakan respon dari perlakuan menunjukkan rata-rata laju pulsus ternak untuk perlakuan kombinasi pengkabutan dan kipas angin $64,12 \pm 5,96$ denyutan/menit dan kontrol $68,44 \pm 5,85$ denyutan/menit. Hasil analisis variansi laju pulsus ternak ketika mendapatkan perlakuan kombinasi pengkabutan dan kipas yang dibandingkan kontrol berbeda nyata $(\mathrm{P} \leq 0,05)$.

Hasil pengukuran laju respirasi sapi FH yang merupakan respon dari perlakuan menunjukkan rata-rata laju pulsus ternak untuk perlakuan kombinasi pengkabutan dan kipas angin 23,56 $\pm 3,36$ dengusan/menit dan kontrol 33,56 $\pm 8,02$ dengusan/menit. Hasil analisis variansi laju respirasi ternak ketika mendapatkan perlakuan kombinasi pengkabutan dan kipas angin yang dibandingkan kontrol sangat berbeda nyata $(\mathrm{P} \leq 0,01)$. Pola perubahan temperatur rektal, laju pulsus, dan laju respirasi ternak yang diberi perlakuan kombinasi pengkabutan dan kipas angin serta kontrol disajikan pada Gambar 3.

Terjadi penurunan temperatur rektal ternak sebesar $0,23^{\circ} \mathrm{C}$ pada kelompok perlakuan dibandingkan kelompok kontrol pada saat dilakukan perlakuan. Hal ini diduga kabut air yang berasal dari nozel menyerap panas tubuh ternak, sehingga beban panas yang dimiliki ternak dapat berkurang atau beban panas tubuh ternak dipindahkan secara konveksi. Konveksi merupakan pertukaran panas melalui substansi materi yang berpindah secara makroskopis (Putra, 2012).

Terjadi penurunan laju pulsus ternak 4,32 denyutan/menit pada kelompok perlakuan dibandingkan kelompok kontrol pada saat dilakukan perlakuan. Tingginya temperatur lingkungan menyebabkan beban panas pada ternak semakin bertambah. Hal ini mengakibatkan laju pulsus meningkat untuk mendistribusi darah yang membawa panas tubuh ke daerah kulit untuk dilepaskan ke lingkungan. Penurunan temperatur tubuh ternak yang merupakan efek perlakuan berpengaruh terhadap laju pulsus ternak.

Tabel 3. Rata-rata temperatur rektal, laju pulsus, dan laju respirasi ternak sapi perah FH (average of rectal temperature, pulsus rate and respiration rate of FH dairy cow)

\begin{tabular}{lccc}
\hline \hline \multicolumn{1}{c}{ Parameter } & $\begin{array}{c}\text { Pengkabutan dan kipas } \\
\text { angin (sprinkler and fan })\end{array}$ & $\begin{array}{c}\text { Kontrol } \\
(\text { control) }\end{array}$ & $\begin{array}{c}\text { Signifikansi } \\
\text { (significancy) }\end{array}$ \\
\hline Temperatur rektal $\left({ }^{\circ} \mathrm{C}\right)\left(\right.$ rectal temperature $\left.\left({ }^{\circ} \mathrm{C}\right)\right)$ & $38,58 \pm 0,35$ & $38,82 \pm 0,41$ & $*$ \\
$\begin{array}{l}\text { Laju pulsus (denyut/menit) (pulsus rate } \\
\text { (beats/minute) }\end{array}$ & $64,12 \pm 5,96$ & $68,44 \pm 5,85$ & $*$ \\
$\begin{array}{l}\text { Laju respirasi (dengusan/menit) (respiration rate } \\
\text { (grunts/minute) }\end{array}$ & $23,56 \pm 3,36$ & $33,56 \pm 8,02$ & $* *$ \\
$*(\mathrm{P} \leq 0,05), * *(\mathrm{P} \leq 0,01)$. & & &
\end{tabular}


(a)

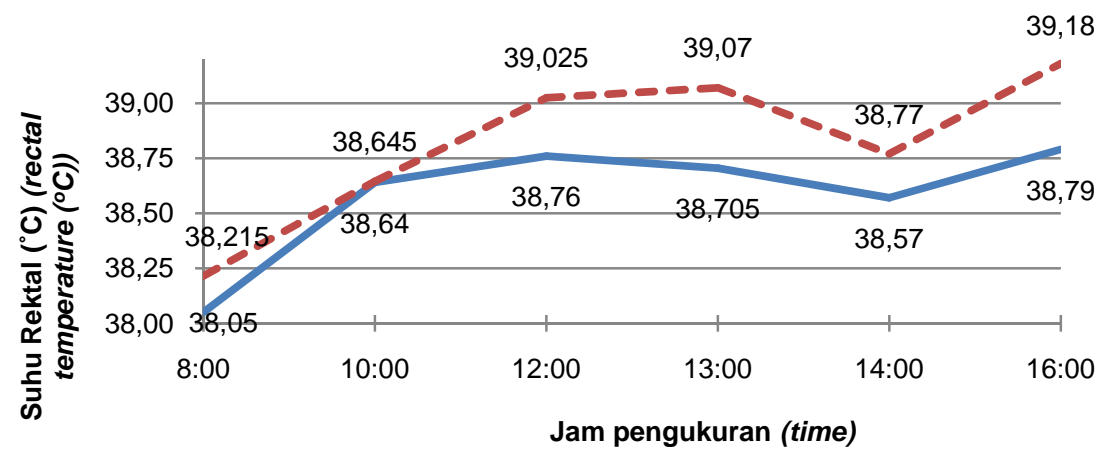

(b)

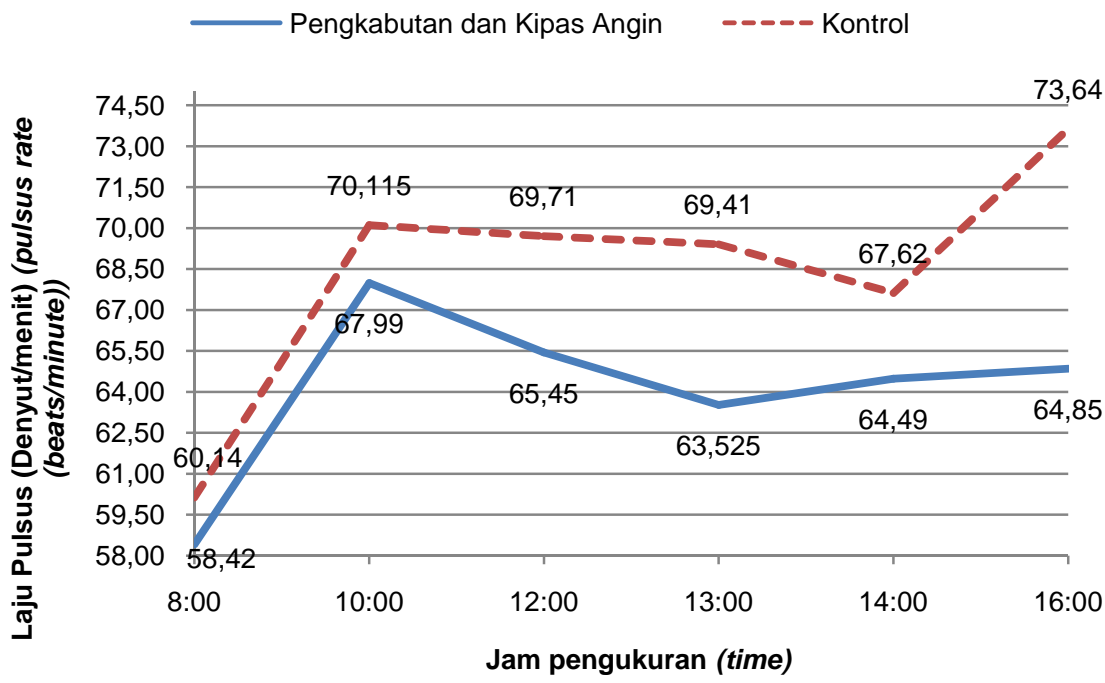

Pengkabutan dan Kipas Angin - - - Kontrol

(c)

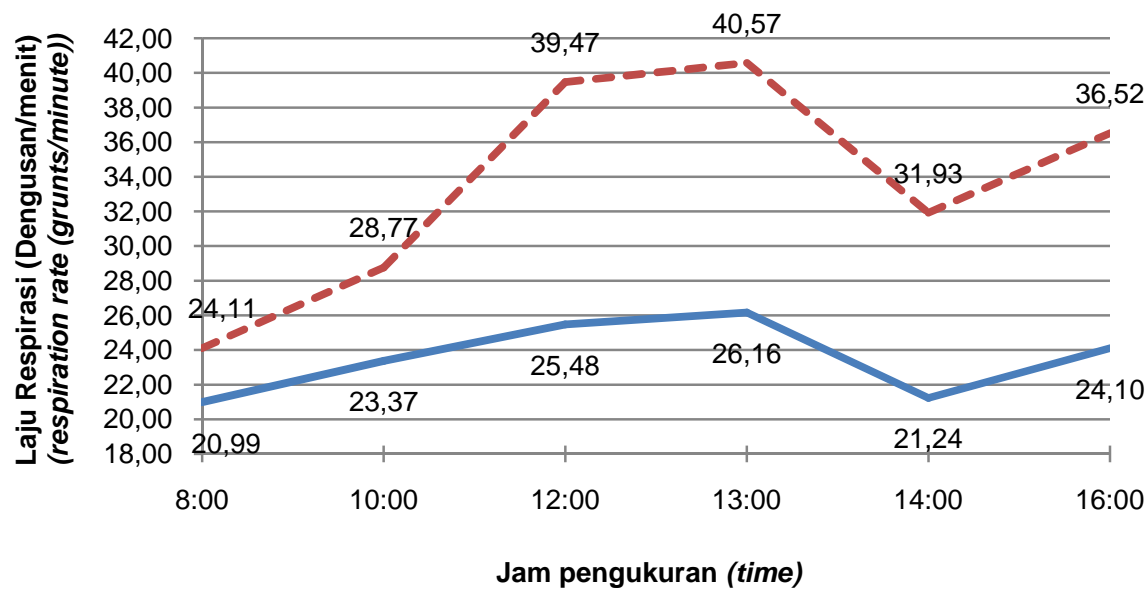

Pengkabutan dan Kipas Angin $\quad----$ Kontrol

Gambar 3. Grafik temperatur rectal (a), laju pulsus (b), dan laju respirasi (c) ternak untuk kedua kelompok perlakuan (graphic of rectal temperature (a), pulsus rate (b) and respiration rate (c) for two treatments).

Terjadi penurunan laju respirasi ternak 10,01 dengusan/menit pada kelompok perlakuan dibandingkan kelompok kontrol pada saat dilakukan perlakuan. Salah satu upaya ternak untuk melepaskan beban panas dengan cara evaporasi melalui saluran pernapasan. Bernafas pendekpendek dan cepat merupakan tanda bahwa hewan itu kepanasan (Putra, 2012). Tingginya temperatur lingkungan mengakibatkan laju respirasi pada kelompok kontrol lebih tinggi dibandingkan kelompok perlakuan.

Hubungan Temperature-Humidity Index (THI) dengan kondisi fisiologis

$$
\text { Temperature-Humidity Index }
$$
merupakan kombinasi temperatur dan kelembaban 
lingkungan yang menjadi indikator kenyamanan lingkungan sapi perah. Ternak sapi perah FH akan mengalami gangguan jika THI melampaui angka 72 (Amstrong, 1994). Hubungan THI dengan kondisi fisiologis sapi $\mathrm{FH}$ pada kelompok perlakuan dan kontrol ditunjukkan pada Gambar 4.

Pada kelompok perlakuan kenaikan THI sebesar 0,51 dari 75,49 menjadi 76,00 diikuti penurunan temperatur rektal, laju pulsus, laju respirasi masing-masing sebesar $0,74^{\circ} \mathrm{C}, 6,43$ denyutan/menit dan 3,11 dengusan/menit. Kenaikan THI sebesar 0,04 dari 76,00 menjadi 76,04 diikuti kenaikan temperatur rektal, laju pulsus, dan laju respirasi masing-masing sebesar $0,71^{\circ} \mathrm{C}, 7,03$ denyutan/menit, dan 4,49 dengusan/menit. Kenaikan THI sebesar 0,28 dari 76,04 menjadi 76,32 diikuti penurunan temperatur rektal, laju pulsus, dan laju respirasi masing-masing sebesar $0,19^{\circ} \mathrm{C}, \quad 0,96$ denyutan/menit, dan 4,24 dengusan/menit. Kenaikan THI sebesar 0,01 dari 76,32 menjadi 76,33 diikuti kenaikan temperatur rektal, laju pulsus, dan laju respirasi masing-masing sebesar $0,08^{\circ} \mathrm{C}, 3,50$ denyutan/menit, dan 2,13 dengusan/menit. Kenaikan THI sebesar 0,27 dari 76,33 menjadi 76,60 diikuti kenaikan temperatur rektal, laju pulsus, dan laju respirasi masing-masing sebesar $0,06^{\circ} \mathrm{C}, 4,46$ denyutan/menit, dan 2,79 dengusan/menit.
Pada kelompok kontrol kenaikan THI sebesar 1,95 dari 76,36 menjadi 77,91 diikuti peningkatan temperatur rektal, laju pulsus, dan laju respirasi masing-masing sebesar $0,96^{\circ} \mathrm{C}, \quad 13,50$ denyutan/menit, dan 12,41 dengusan/menit. Kenaikan THI sebesar 0,40 dari 77,91 menjadi 78,31 diikuti penurunan temperatur rektal, laju pulsus, dan laju respirasi masing-masing sebesar $0,53^{\circ} \mathrm{C}, \quad 3,53$ denyutan/menit, dan 7,76 dengusan/menit. Kenaikan THI sebesar 1,04 dari 78,31 menjadi 79,35 diikuti peningkatan temperatur rektal dan laju respirasi masing-masing sebesar $0,12^{\circ} \mathrm{C}$, dan 3,17 dengusan/menit, sedangkan laju pulsus terjadi penurunan sebesar 2,49 denyutan/menit. Kenaikan THI sebesar 0,32 dari 79,35 menjadi 79,67 diikuti peningkatan temperatur rektal, laju pulsus, laju respirasi masing-masing sebesar $0,25^{\circ} \mathrm{C}, 2,09$ denyutan/menit, dan 7,54 dengusan/menit. Kenaikan THI sebesar 1,24 dari 79,67 menjadi 80,91 diikuti peningkatan temperatur rektal dan laju respirasi masing-masing sebesar $0,05^{\circ} \mathrm{C}$ dan 1,10 dengusan/menit sedangkan laju pulsus terjadi penurunan sebesar 0,30 denyutan/menit. Fluktuasi fisiologi ini diduga dipengaruhi oleh aktivitas ternak, yaitu aktivitas makan, bergerak, dan mencerna pakan.
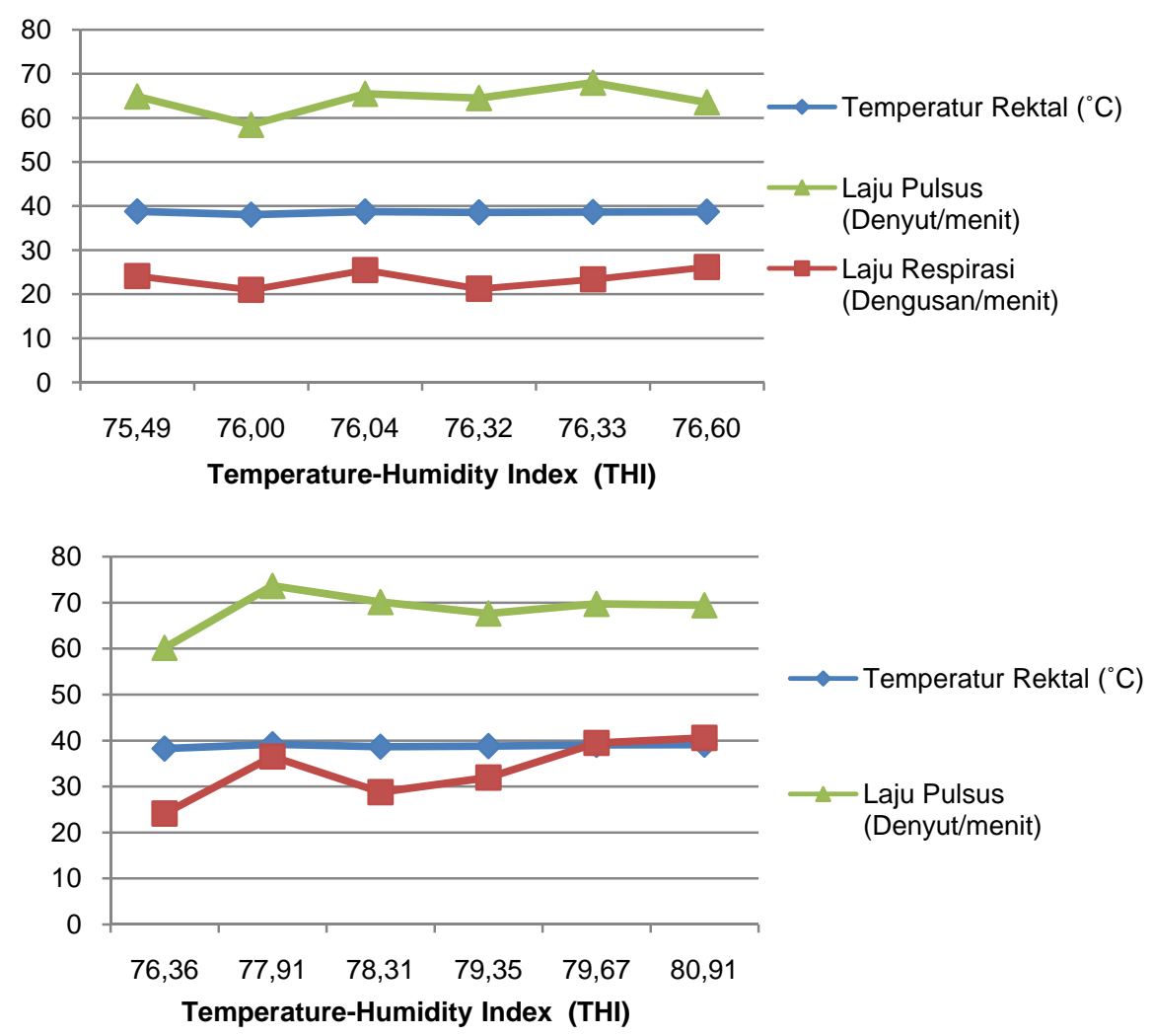

Gambar 4. Grafik pola hubungan antara Temperature-Humidity Index (THI) dengan kondisi fisiologi pada kedua kelompok sapi Friesian Holstein (graphic of relationship of THI and physiology conditions on two Friesian Holstein dairy cattle treatments). 


\section{Konsumsi pakan}

Konsumsi pakan ternak perah di UPT Ternak Perah UGM terdiri atas hijauan rumput king grass Thailand dan campuran ampas tahu dan polar. Pemberian rumput sebanyak $17 \mathrm{~kg} / \mathrm{ekor} / \mathrm{hari}$ diberikan sebanyak tiga kali sehari. Campuran ampas tahu dan polar dengan perbandingan 1:1 diberikan dua kali sehari sebanyak $7 \mathrm{~kg} / \mathrm{ekor} / \mathrm{hari}$.

Konsumsi BK sapi perah sebesar 15,64 $\mathrm{kg} / \mathrm{ekor} /$ hari, protein $1,27 \mathrm{~kg} / \mathrm{ekor} /$ hari, lemak kasar $0,46 \mathrm{~kg} / \mathrm{ekor} / \mathrm{hari}$ dan serat kasar 4,48 kg/ekor/hari. Kebutuhan konsumsi BK sapi perah sebesar 3\% dari berat hidup ternak (Moran, 2005). Berdasarkan berat badan sapi yaitu 409,13 $\pm 19,02 \mathrm{~kg}$, maka kebutuhan konsumsi BK sebesar 12,27 kg. Pemberian pakan sebesar 15,64 kg/ekor/hari melebihi kebutuhan konsumsi pakan BK. Pakan yang diberikan ke ternak habis dikonsumsi baik pada kelompok perlakuan maupun kelompok kontrol. Hal ini diduga stres panas yang dialami ternak belum mempengaruhi konsumsi ternak. Menurut Rhoads et al. (2009) penurunan konsumsi BK disebabkan oleh stres panas mengakibatkan penurunan produksi susu sebesar 35\%.

\section{Kesimpulan}

Berdasarkan hasil yang diperoleh dalam penelitian ini dapat disimpulkan bahwa perlakuan kombinasi pengkabutan dan kipas angin selama 10 menit dapat menurunkan temperatur lingkungan dalam kandang, efektif menurunkan TemperatureHumidity Index (THI) kandang, serta temperatur rektal, laju pulsus, dan laju respirasi ternak, namun menaikkan kelembaban dalam kandang. Konsumsi pakan ternak tidak dipengaruhi oleh stres panas. Perlakuan kombinasi pengkabutan dan kipas angin perlu dilakukan setiap jam selama 10 menit untuk mengurangi beban panas tubuh pada sapi FH. Perlu dilakukan penelitian pendingin kandang dengan sistim otomatis, dimana temperatur dan kelembaban kandang dipertahankan stabil.

\section{Daftar Pustaka}

Armstrong, D. V. 1994. Heat stress interaction with shade and cooling. J. Dairy Sci. 77: 20442050.

Chase, E. L. 2006. Climate change impacts on dairy cattle. Climate Change and Agriculture: Promoting Practical and Profitable Responses. Ithaca, New York.

Gaspersz, V. 1992. Teknik Analisis dalam Penelitian Percobaan. Tarsito, Bandung. Pp. 260-267.

Moran, J. 2005. Tropical Dairy Farming. Feeding Management for Small Holder Dairy Farmers in the Humid Tropics. Department of Primary Industries. CSIRO Published Victoria Australia.

Putra, D. K. H. 2012. Fisiologi Hewan: Thermoregulasi. Udayana University Press. Denpasar.

Rhoads, M. L., R. P. Rhoads, M. J. VanBaale, R. J. Collier, S. R. Sanders, W. J. Weber, B. A. Crooker and L. H. Baumgard. 2009. Effects of heat stress and plane of nutrition on lactating Holstein cows: I. Production, metabolism and aspects of circulating somatotropin. J. Dairy Sci. 92: 1986-1997.

Yani, A. dan B. P. Purwanto. 2006. Pengaruh iklim terhadap respon sapi peranakan Fries Holland dan modifikasi lingkungan untuk meningkatkan produktivitasnya. Media Peternakan 9: 35-46.

Yani, A., Suhardiyanto, R. Hasbullah, dan B. P. Purwanto. 2007. Analisis dan simulasi distribusi suhu udara pada kandang sapi perah menggunakan computational fluid dynamics (CFD). Media Peternakan 30: 218228. 